University of Nebraska - Lincoln

DigitalCommons@University of Nebraska - Lincoln

\title{
The impact of buffer strips and stream-side grazing on small mammals in southwestern Wisconsin
}

\author{
Erik W. Chapman \\ University of Wisconsin, erik.chapman@unh.edu \\ Christine A. Ribic \\ University of Wisconsin, caribic@facstaff.wisc.edu
}

Follow this and additional works at: https://digitalcommons.unl.edu/usgsstaffpub

Chapman, Erik W. and Ribic, Christine A., "The impact of buffer strips and stream-side grazing on small mammals in southwestern Wisconsin" (2002). USGS Staff -- Published Research. 522.

https://digitalcommons.unl.edu/usgsstaffpub/522

This Article is brought to you for free and open access by the US Geological Survey at DigitalCommons@University of Nebraska - Lincoln. It has been accepted for inclusion in USGS Staff -- Published Research by an authorized administrator of DigitalCommons@University of Nebraska - Lincoln. 


\title{
The impact of buffer strips and stream-side grazing on small mammals in southwestern Wisconsin
}

\author{
Erik W. Chapman, Christine A. Ribic* \\ USGS BRD Wisconsin Cooperative Wildlife Research Unit, Department of Wildlife Ecology, \\ University of Wisconsin, 218 Russell Labs, 1630 Linden Drive, Madison, WI 53706, USA
}

Received 9 June 2000; received in revised form 15 December 2000; accepted 15 December 2000

\begin{abstract}
The practice of continuously grazing cattle along streams has caused extensive degradation of riparian habitats. Buffer strips and managed intensive rotational grazing (MIRG) have been proposed to protect and restore stream ecosystems in Wisconsin. However, the ecological implications of a switch from traditional livestock management to MIRG or buffer strip establishment have not been investigated. Differences in small mammal communities associated with riparian areas on continuously grazed and MIRG pastures, as well as vegetative buffer strips adjacent to row crops, were investigated in southwestern Wisconsin during May-September 1997 and 1998. More species (mean of 6-7) were found on the buffer sites than on the pasture sites (mean of 2-5). Total small mammal abundance on buffer sites was greater than on the pastures as well; there were 3-5 times as many animals on the buffer sites compared to the pasture sites, depending on year. There were no differences in species richness or total abundance between MIRG and continuously grazed pastures in either year. Total small mammal abundance was greater near the stream than away from the stream, regardless of farm management practice but there were no differences in species richness. Buffer strips appear to support a particularly rich and abundant small mammal community. Although results did not detect a difference in small mammal use between pasture types, farm-wide implications of a conversion from continuous to MIRG styles of grazing may benefit small mammals indirectly by causing an increase in the prevalence of pasture in the agricultural landscape. Published by Elsevier Science B.V.
\end{abstract}

Keywords: Grazing; Buffer strips; Small mammals; Stream-side grazing; Southwestern Wisconsin

\section{Introduction}

As in many agricultural regions in the US, traditional grazing practices involving continuously grazing cattle along streams have caused extensive degradation of riparian habitats in Wisconsin (Kauffman and Krueger, 1984; Wohl and Carline, 1996). Efforts to improve the health of riparian areas typically focus on establishing buffer strips along streams

\footnotetext{
* Corresponding author. Tel.: +1-608-263-6556; fax: +1-608-263-4519.

E-mail address: caribic@facstaff.wisc.edu (C.A. Ribic).
}

that exclude grazing (Kauffman and Krueger, 1984; Barling and Moore, 1994; Castelle et al., 1994; Rabeni and Smale, 1995). This practice usually leads to improvements in stream quality but is considered impractical by many farmers because buffer strips do not allow continued access to riparian areas for agricultural uses (Platts and Wagstaff, 1984). Managed intensive rotational grazing (MIRG) of livestock has recently been proposed as an alternative to buffer strips for protecting and restoring stream ecosystems in Wisconsin (Undersander et al., 1992). MIRG systems are believed to improve stream-bank stability while providing a more financially solvent farm 
management practice than traditional livestock management. Therefore, MIRG pasturing may satisfy both environmental and socio-economic concerns. However, the ecological implications of a switch from traditional livestock management to MIRG or buffer strip establishment have not been investigated. Because small mammals are closely tied to small-scale vegetation structure, they are likely to respond to differences in cover and disturbance regime inherent to riparian management practices.

Although previous studies have found that prominent land use practices in the agricultural landscape, such as cultivated and hayed fields (25 and $35 \%$ of the total farm land, Wisconsin Agricultural Statistics Service, 1996) support a limited small mammal community (Fleharty and Navo, 1983; Sietman et al., 1994; Marinelli and Neal, 1995), the value of pastures (20\% of the overall land in farm in southwestern Wisconsin, Wisconsin Agricultural Statistics Service, 1996), particularly in riparian areas, remains unknown. Riparian areas may also function as habitat corridors that may compensate for the negative impacts associated with a highly fragmented agricultural landscape (Noss, 1983; Fahrig and Merriam, 1985).

The primary objective of this research was to assess differences in small mammal communities associated with riparian areas in southwestern Wisconsin on continuously grazed and MIRG pastures, as well as vegetative buffer strips adjacent to row crops (a farm arrangement likely to occur if farmers are required to fence out stream areas from grazing). A second objective was to investigate whether there was a concentration of small mammal activity immediately adjacent to streams compared to areas a short distance away. This objective was intended to investigate whether stream areas may be a particularly attractive landscape feature to small mammals.

\section{Materials and methods}

\subsection{Area description}

Small mammals and vegetation structure were sampled from five MIRG pastures, four continuously grazed (continuous) pastures, and four buffer strips adjacent to planted corn, or soybeans, during May-September, 1997 and 1998. Study sites were located on cold-water streams in southwestern Wisconsin as part of an interdisciplinary study investigating alternative management of riparian zones (Renfrew and Ribic, 2001; Weigel et al., 2000). All sites had been managed as a pasture or buffer strip for at least 5 years. One MIRG site was replaced in 1998 because of a change in livestock management, otherwise, the same sites were sampled in both years.

MIRG sites experienced stocking densities between 50-70 animal units (au) per hectare in each paddock (pasture subdivisions) during grazing episodes. Stocking rates on these sites ranged from $1.4 \mathrm{au} \mathrm{ha}^{-1}$ per day to $1.7 \mathrm{au} \mathrm{ha}^{-1}$ per day. Periods between grazing episodes in each paddock ranged from 2 to 5 weeks, increasing in duration through the summer. Overall, MIRG pastures were 36.5 ha on average [22.0 standard deviation (S.D.)] and paddocks were $3.6 \mathrm{ha}$ on average (3.6 S.D.). Some MIRG systems also included additional pastures in nearby riparian or upland areas, increasing the overall pasture size for each farm. Following grazing episodes, vegetation height was generally less than $0.2 \mathrm{~m}$, but increased during the rest period to around 0.5 or $1.0 \mathrm{~m}$. Continuously grazed sites experienced a stocking density between 0.38 and $0.97 \mathrm{auha}^{-1}$. Pastures on continuously grazed farms were 20.0 ha in size on average (14.9 S.D.). Vegetation height averaged $0.7 \mathrm{~m}$ throughout the summer. Sedge species (Carex spp.), bluegrass (Poa pratensis), reed canary grass (Phalaris arundinacea), quack grass (Agropyron repens), foxtail species (Setaria spp.), smartweed (Polygonum persicaria), jewel weed (Impatiens pallida), white clover (Trifolium repens), rye grass (Lolium perenne), and dandelion (Taraxacum officinale) were common plant species found on both MIRG and continuous pastures (botanical nomenclature; Curtis, 1959). Both MIRG and continuous sites had little to no litter layer that typically ranged between 0 and $10 \mathrm{~cm}$.

Buffer sites had an ungrazed grassy strip between 7 and $15 \mathrm{~m}$ in width along each side of the stream and were 1.3 ha on average ( 0.5 S.D.). Corn was grown adjacent to the buffer strip on all four sites in 1997. On two sites in 1998, farmers planted soybean in place of corn on at least one side of the stream. Cultivated fields were 13.4 ha on average (6.7 S.D.). Reed canary grass was the dominant plant species in the grassy buffer strips. Other species found in the buffer strips included sedge species, bluegrass, goldenrod (Solidago spp.), 
smooth brome grass (Bromus inermis), and stinging nettle (Urtica dioica). Vegetation height in the buffer was about $0.8 \mathrm{~m}$ in May and increased to about $1.4 \mathrm{~m}$ in September. Buffer strips had an extensive litter layer that was typically $10-100 \mathrm{~cm}$ deep. Corn and soybean fields were entirely bare ground in May when crops were planted and had matured by late August to approximately 2.0 and $0.8 \mathrm{~m}$, respectively.

\subsection{Trapping techniques}

Four $270 \mathrm{~m}$ transects were established at each site, each oriented parallel to the stream. Two transects were established on each side of the stream, one within $5 \mathrm{~m}$ of the stream (stream transect) and one approximately $30 \mathrm{~m}$ from the stream (non-stream transect). Transects were placed greater than $30 \mathrm{~m}$ from adjacent habitats. When an adjacent habitat was too close to the non-stream transect, a second non-stream transect $60 \mathrm{~m}$ from the stream was placed on the other side of the stream. Trapping stations were located at $30 \mathrm{~m}$ intervals along each transect where two Sherman live traps were placed. The trapping array included 23 medium sized $(7.6 \mathrm{~cm} \times 8.9 \mathrm{~cm} \times 22.9 \mathrm{~cm}$ folding, aluminum) and 47 small $(5.1 \mathrm{~cm} \times 6.4 \mathrm{~cm} \times 16.5 \mathrm{~cm}$ both folding and non-folding, aluminum) Sherman live traps. Traps were baited with a wild bird seed mixture containing a variety of grains and other seeds. Drift fences with pitfall traps were used to sample species such as shrews that are not effectively captured in live traps (Handley and Kalko, 1993; Anthony, 1999). Four $10 \mathrm{~m}$ drift fences, each with four pitfall traps, were placed in line with each transect but greater than $50 \mathrm{~m}$ from any live trap.

Sites were trapped four times during 1997 and 1998. Trapping began 15 May and ended 15 September during both years and trapping sessions were separated by $2-4$ weeks. Four sites were trapped at a time, including at least one site from each treatment. Because small mammals may respond to growth cycles during the rest period, attempts were made to sample MIRG sites alternately immediately after and just before grazing episodes. Total trap nights (TN) was 37,585 for combined Sherman and pitfall traps over the course of the study. Field techniques followed guidelines outlined in the Ad Hoc Committee on Acceptable Field Methods in Mammalogy (1987). Trapping periods lasted for five trapping nights. Traps were checked at sunset on sites occupied by diurnal species such as thirteen-lined ground squirrel (Spermophilus tridecemlineatus). At each capture, species, sex, age, weight, and body length were recorded. An individually numbered Monel ear tag (National Band and Tag Co., Newport, Kentucky) was attached to the ear of each animal. In the case of shrews, a small dot of paint was placed on the back of the head to identify recaptures. Animals were then released at the point of capture. No attempt was made to positively identify species of the genus Peromyscus because, in southwestern Wisconsin, white-footed mice (Peromyscus leucopus) and deer mice (Peromyscus maniculatus) are difficult to distinguish in the field (Anthony, 1999).

\subsection{Analyses of mammal population}

The small mammal community was defined as all unique adult individuals captured over the four trapping sessions from May to September; the definition of an adult for all species was taken from parameters in Jackson (1961).

Relative abundance for each species and total abundance for all species combined were the total number of unique individuals captured per 1000 trap nights. Because the ratio of live-trap to pitfall trap effort was similar for each trapping session, data from the two trap types were combined in abundance calculations. Effort for abundance calculations was corrected for missing, destroyed, and sprung traps as follows: effort $=N-0.5 S-M$ where $N=$ total number of traps, $S=$ number of sprung traps, and $M=$ number of missing or destroyed traps (Nelson and Clark, 1973).

Diversity was indexed for each site using species richness, total abundance, the Shannon evenness measure (Pielou, 1969; Magurran, 1988), and the Berger-Parker dominance measure (Berger and Parker, 1970). Species richness, relative abundance for species, and total small mammal abundance were also calculated for stream and non-stream transects within each site. Total abundance of all species combined was used in further analyses.

Comparisons of richness, abundance and the diversity indices between the buffer and pasture treatments were made using a repeated measures ANOVA. Within treatments, species richness and total 
abundance were compared using a repeated measures ANOVA with a split-plot design; location (stream and non-stream) was the within pasture factor. If the interaction between treatment and year was significant at $P<0.05$ for any analysis, analyses by year were conducted. All variables were transformed for normality, using an arcsine square root transformation for proportions (Shannon evenness, Berger-Parker dominance) or a log transformation (richness, relative abundance) (Mosteller and Tukey, 1977; Sokal and Rohlf, 1995). Posterior investigations of treatment differences were conducted using Tukey's honestly significant difference test (the one-way ANOVA) and $t$-tests with a Bonferroni correction (split-plot factor) (Keppel, 1991).

\subsection{Vegetation methods and analysis}

Vegetation-height-density and litter layer depth were used to index the amount of available cover. Vegetation variables were sampled during the first two small mammal sampling sessions. Four litter layer depth $(\mathrm{cm})$ measurements were taken within a $1 / 2 \mathrm{~m} \times 1 / 2 \mathrm{~m}$ square sampling station immediately adjacent to each live trap and drift-fence. Visual obstruction readings at $4 \mathrm{~m}$ from a Robel pole at a height of $1 \mathrm{~m}$ were also taken at each sampling station (Robel et al., 1970). Vegetation sampling was not conducted in non-stream areas of buffer sites to avoid damaging crops. Mean Robel height and litter depth values for cover variables were summarized for each year by treatment and location. Differences between vegetation variables along the stream between buffer and pasture treatments were tested with a repeated measures analysis. Within pasture treatments, vegetation variables were compared using a repeated measures ANOVA with a split-plot design; location (stream and non-stream) was the within pasture factor.

For all tests, significance was assessed at alpha $=$ 0.05 and trends at 0.10 . Analyses were conducted using SAS PROC MIXED (Littell et al., 1996) and STATISTICA (StatSoft, 1998).

\section{Results}

Overall 1379 individuals from 14 species were captured during the study. Of these, 343 individuals and
10 species were caught in 1997 and 1036 individuals and 14 species were caught in 1998. The dramatic increase in captures of individuals and species was experienced across all treatments. Relative abundance of species with greater than 10 overall captures are reported in Table 1.

\subsection{Comparisons between farm management and mammal species}

Significantly more species were found on the buffer sites than on either pasture type during both years of the study (Table 2); the pattern was the same between years (interaction $P$-value $=0.086$ ). Total small mammal abundance on buffer sites was significantly greater than on the pastures as well. The pattern changed between years (interaction $P$-value $=$ 0.019 ); there were 3-5 times as many animals on the buffer sites compared to the pasture sites, depending on year (Table 2). There were no differences in species richness or total abundance between MIRG and continuous pastures in either year. Species found on buffer sites that were relatively uncommon on pastures included western harvest mouse (Reithrodontomys megalotis), masked shrew (Sorex cinereus), short-tailed shrew (Blarina brevicauda), house mouse (Mus musculus) and Peromyscus spp. (Table 1). Meadow voles (Microtus pennsylvanicus) were the most abundant species found on both pasture types while Peromyscus spp. was the most abundant species captured on buffer sites during both years of the study. Prairie voles (Microtus ochrogaster) were confirmed on both pasture types but not on the buffer sites.

Small mammal communities tended to be more even on the buffer sites compared to the pasture sites in both years though dominance did not change (Table 2); this pattern did not change with year (interaction $P$-values $>0.20$, both tests). In 1998, there was an increase in captures of shorttailed shrews, meadow voles, house mice and western harvest mice on the buffer sites which caused an increase in Shannon evenness and a decrease in dominance compared to 1997. There was a decrease in dominance in communities on continuously grazed pastures from 1997 to 1998 as well. This was due to an increase in captures of short-tailed shrews in 1998. 
Table 1

Mean and range of relative abundance values (AB; \# captures/1000 TN) for small mammals by farm management practice and location within farm

\begin{tabular}{|c|c|c|c|c|c|c|c|c|c|c|c|c|c|}
\hline \multirow[b]{3}{*}{ Species } & \multirow[b]{3}{*}{ Year } & \multicolumn{4}{|c|}{ Continuous } & \multicolumn{4}{|c|}{ MIRG* $^{*}$} & \multicolumn{4}{|c|}{ Buffer } \\
\hline & & \multicolumn{2}{|c|}{ Stream } & \multicolumn{2}{|c|}{ Non-stream } & \multicolumn{2}{|c|}{ Stream } & \multicolumn{2}{|c|}{ Non-stream } & \multicolumn{2}{|c|}{ Stream } & \multicolumn{2}{|c|}{ Non-stream } \\
\hline & & $\mathrm{AB}$ & Range & $\mathrm{AB}$ & Range & $\mathrm{AB}$ & Range & $\mathrm{AB}$ & Range & $\mathrm{AB}$ & Range & $\mathrm{AB}$ & Range \\
\hline \multirow[t]{2}{*}{ Peromyscus spp. } & 1997 & 1.8 & $0.0-4.2$ & 1.5 & $0.0-5.8$ & 0.0 & 0.0 & 0.3 & $0.0-1.2$ & 14.5 & $0.0-34.2$ & 14.8 & $1.3-22.6$ \\
\hline & 1998 & 4.3 & $0.0-13.3$ & 1.1 & $0.0-4.5$ & 0.3 & $0.0-1.2$ & 0.0 & 0.0 & 22.7 & $3.8-36.2$ & 37.4 & $18.0-56.4$ \\
\hline Meadow vole & 1997 & 1.8 & $0.0-4.2$ & 2.3 & $0.0-6.5$ & 7.2 & $0-14.1$ & 2.4 & $0.0-7.2$ & 16.4 & $11.9-21.1$ & 1.5 & $0.0-4.8$ \\
\hline Microtus pennsylvanicus & 1998 & 18.5 & $6.4-32.5$ & 12.4 & $0.0-35.0$ & 32.5 & $12.8-52.4$ & 14.9 & $13.0-14.9$ & 48.1 & $34.0-63.7$ & 4.2 & $0.0-10.7$ \\
\hline Meadow jumping mouse & 1997 & 1.0 & $0-4.1$ & 0.3 & $0.0-1.3$ & 3.5 & $0.0-10.6$ & 0.0 & 0.0 & 15.1 & $0.0-29.7$ & 0.6 & $0.0-2.4$ \\
\hline Zapus hudsonius & 1998 & 2.9 & $0.0-9.1$ & 0.0 & 0.0 & 4.1 & $0.0-7.9$ & 0.0 & 0.0 & 20.5 & $8.4-41.5$ & 1.3 & $1.2-1.3$ \\
\hline Short-tailed shrew & 1997 & 0.0 & 0.0 & 0.0 & 0.0 & 0.0 & 0.0 & 0.0 & 0.0 & 6.2 & $1.2-16.4$ & 0.3 & $0.0-1.2$ \\
\hline Blarina brevicauda & 1998 & 3.2 & $0.0-7.8$ & 1.3 & $0.0-5.2$ & 5.4 & $2.4-8.7$ & 1.2 & $0.0-2.4$ & 46.7 & $31.3-63.1$ & 4.9 & $1.3-10.0$ \\
\hline Masked shrew & 1997 & 0.0 & 0.0 & 0.0 & 0.0 & 0.6 & $0.0-2.4$ & 0.9 & $0.0-2.4$ & 2.4 & $0.0-7.0$ & 0.3 & $0.0-1.2$ \\
\hline Sorex cinereus & 1998 & 0.3 & $0.0-1.2$ & 0.3 & $0.0-1.3$ & 1.2 & $0.0-4.7$ & 3.9 & $0.0-7.1$ & 8.3 & $4.8-14.6$ & 1.3 & $0.0-2.4$ \\
\hline Western harvest mouse & 1997 & 0.0 & 0.0 & 0.0 & 0.0 & 0.0 & 0.0 & 0.0 & 0.0 & 1.5 & $0.0-4.7$ & 0.0 & 0.0 \\
\hline Reithrodontomys megalotus & 1998 & 0.0 & 0.0 & 0.0 & 0.0 & 0.0 & 0.0 & 0.0 & 0.0 & 4.1 & $0.0-7.6$ & 4.3 & $0.0-11.2$ \\
\hline Thirteen-lined ground squirrel & 1997 & 2.4 & $0.0-8.5$ & 1.5 & $0.0-5.8$ & 0.9 & $0.0-3.6$ & 0.9 & $0.0-3.6$ & 0.3 & $0.0-1.2$ & 0.3 & $0.0-1.3$ \\
\hline Spermophilus tridecemlineatus & 1998 & 3.2 & $0.0-8.0$ & 2.6 & $0.0-8.9$ & 0.0 & 0.0 & 3.0 & $0.0-12.1$ & 0.0 & 0.0 & 0.0 & 0.0 \\
\hline House mouse & 1997 & 0.0 & 0.0 & 0.0 & 0.0 & 0.0 & 0.0 & 0.0 & 0.0 & 0.3 & $0.0-1.2$ & 0.0 & 0.0 \\
\hline Mus musculus & 1998 & 0.3 & $0.0-1.3$ & 0.0 & 0.0 & 0.0 & 0.0 & 0.0 & 0.0 & 0.3 & $0.0-1.3$ & 4.3 & $0.0-14.8$ \\
\hline
\end{tabular}

* MIRG: managed intensive rotational grazing. 
Table 2

Average diversity values with standard errors (S.E.) by farm management practice

\begin{tabular}{|c|c|c|c|c|c|c|c|c|}
\hline \multirow[b]{2}{*}{ Statistic } & \multirow[b]{2}{*}{ Year } & \multicolumn{2}{|c|}{ Continuous } & \multicolumn{2}{|c|}{ MIRG* } & \multicolumn{2}{|l|}{ Buffer } & \multirow{2}{*}{$\begin{array}{l}P \text {-value for treatmen } \\
\text { differences }\end{array}$} \\
\hline & & Value & S.E. & Value & S.E. & Value & S.E. & \\
\hline \multirow[t]{2}{*}{ Shannon evenness } & 1997 & 0.27 & 0.09 & 0.29 & 0.10 & $0.53^{\mathrm{c}, \mathrm{d}}$ & 0.05 & \multirow[t]{2}{*}{0.051} \\
\hline & 1998 & 0.41 & 0.03 & 0.36 & 0.05 & $0.60^{c, d}$ & 0.01 & \\
\hline \multirow[t]{2}{*}{ Berger-Parker dominance } & 1997 & 0.74 & 0.12 & 0.66 & 0.11 & 0.51 & 0.09 & \multirow[t]{2}{*}{0.21} \\
\hline & 1998 & 0.58 & 0.07 & 0.69 & 0.06 & 0.34 & 0.03 & \\
\hline \multirow[t]{2}{*}{ Richness } & 1997 & 2.0 & 0.4 & 2.5 & 0.5 & $5.8^{\mathrm{a}, \mathrm{b}}$ & 0.3 & \multirow[t]{2}{*}{$<0.001$} \\
\hline & 1998 & 5.0 & 0.4 & 5.0 & 0.4 & $7^{\mathrm{a}, \mathrm{b}}$ & 0 & \\
\hline \multirow[t]{2}{*}{ Abundance $^{* *}$ (\# captures/1000 TN) } & 1997 & 6.7 & 2.7 & 8.6 & 2.2 & $46.9^{\mathrm{a}, \mathrm{b}}$ & 6.1 & 0.001 \\
\hline & 1998 & 27.8 & 8.5 & 35.3 & 5.6 & $118.6^{\mathrm{a}, \mathrm{b}}$ & 14.7 & 0.014 \\
\hline
\end{tabular}

${ }^{a}$ Significantly greater than continuous results, $P<0.05$.

${ }^{\mathrm{b}}$ Significantly greater than MIRG results, $P<0.05$.

${ }^{\mathrm{c}}$ Tended to be greater than continuous results, $P<0.10$.

d Tended to be greater than MIRG results, $P<0.10$.

* MIRG: managed intensive rotational grazing.

** Analyses were run separately by year due to a significant interaction between treatment and year.

\subsection{Mammal species richness and abundance near streams}

Differences in species richness near and away from the stream depended on year (interaction $P$-value $\leq$ 0.001). In 1997, more species rich small mammal communities were found in stream areas (mean $=3.0$, S.D. $=1.9)$ compared to non-stream areas (mean $=$ 1.8 , S.D. $=1.1$ ) regardless of farm management practice. In 1998, several species common in buffer strips (near the stream) such as meadow voles, short-tailed shrews and western harvest mice were also captured in the crop fields (away from stream). As a result, more species were not detected in stream areas (mean $=$ 4.9, S.D. $=1.6)$ than non-stream areas $($ mean $=3.8$, S.D. $=2.2$ ) on buffer sites in 1998.

In both years, total abundance was greater near the stream than away from the stream, regardless of farm management practice (Table 3), though the pattern was different between the years (interaction $P$-value $<0.001)$. In 1997 , there was almost three times as many animals near the stream compared to away; there was an average of 25.5 animals/1000 TN close to the stream (S.E. $=7.2$ ) and an average of 9.3 animals $/ 1000 \mathrm{TN}$ away from the stream $($ S.E. $=2.7$ ). In 1998, there was about twice as many animals near the stream compared to away; there was an average of 76.1 animals/1000 TN (S.E. $=17.2)$ close to the stream and an average of 33.2 animals $/ 1000$ $\mathrm{TN}$ (S.E. = 7.0) away from the stream. On MIRG and continuous pastures, meadow voles, meadow jumping mice (Zapus hudsonius), and short-tailed shrews were more frequently captured close to the stream than away from the stream (Table 1). Within the buffer strips (near the stream), the most common species in both years was the meadow vole (Table 1). Meadow jumping mouse, Peromyscus spp., masked shrew, short-tailed shrew, masked shrew and western harvest mouse were also common species within the buffer strips (near the stream) (Table 1). Peromyscus spp. was overwhelmingly the most prevalent species captured away from the stream in crop fields and western harvest mice were captured in the crop fields in 1998 (Table 1).

\subsection{Vegetation structure}

Along the stream, litter was deeper in the buffers compared to the pasture treatments in both years $(P<$ $0.001)$ but vegetation height densities were the same $(P>0.25)$ (Table 4); this pattern was the same regardless of year (interaction $P$-value $=0.22$ ). Within pastures, there were no differences between litter depth and vegetation height density near or away from the stream $(P>0.25$, both tests) regardless of year (interaction $P$-value $>0.10$ ) (Table 4$)$. 
Table 3

Average species richness and total abundance (\# captures/1000 TN) values with standard errors (S.E.) of small mammals by farm management practice and location

\begin{tabular}{|c|c|c|c|c|c|c|c|c|c|c|c|c|c|c|}
\hline \multirow[b]{3}{*}{ Statistics } & \multirow[b]{3}{*}{ Year } & \multicolumn{4}{|c|}{ Continuous } & \multicolumn{4}{|c|}{ MIRG* } & \multicolumn{4}{|l|}{ Buffer } & \multirow{3}{*}{$\begin{array}{l}P \text {-value for location } \\
\text { differences }\end{array}$} \\
\hline & & \multicolumn{2}{|c|}{ Stream } & \multicolumn{2}{|c|}{ Non-stream } & \multicolumn{2}{|c|}{ Stream } & \multicolumn{2}{|c|}{ Non-stream } & \multicolumn{2}{|l|}{ Stream } & \multicolumn{2}{|c|}{ Non- stream } & \\
\hline & & Value & S.E. & Value & S.E. & Value & S.E. & Value & S.E. & Value & S.E. & Value & S.E. & \\
\hline \multirow[t]{2}{*}{ Richness } & 1997 & 1.8 & 1.0 & 1.3 & 1.0 & 1.8 & 0.5 & 1.8 & 1.3 & 5.5 & 0.6 & 2.5 & 1.0 & 0.022 \\
\hline & 1998 & 4.8 & 1.0 & 2.0 & 1.2 & 3.5 & 1.0 & 3.5 & 2.1 & 6.5 & 1.0 & 6.0 & 1.4 & 0.112 \\
\hline \multirow[t]{2}{*}{ Abundance } & 1997 & 7.0 & 5.8 & 5.6 & 5.2 & 12.2 & 8.4 & 4.5 & 5.3 & 57.2 & 12.3 & 17.8 & 11.4 & 0.012 \\
\hline & 1998 & 33.0 & 16.0 & 17.7 & 16.3 & 43.7 & 21 & 23.9 & 7.9 & 151.5 & 30.7 & 58.1 & 23.6 & 0.003 \\
\hline
\end{tabular}

${ }^{*}$ MIRG: managed intensive rotational grazing.

Table 4

Mean cover values with standard errors in parentheses by land-use and location within farm

\begin{tabular}{|c|c|c|c|c|c|c|c|}
\hline \multirow[b]{2}{*}{ Cover variable } & \multirow[b]{2}{*}{ Location } & \multicolumn{2}{|c|}{ Continuous } & \multicolumn{2}{|l|}{ MIRG* $^{*}$} & \multicolumn{2}{|l|}{ Buffer } \\
\hline & & 1997 & 1998 & 1997 & 1998 & 1997 & 1998 \\
\hline \multirow[t]{2}{*}{ Robel height (dm) } & Stream & $0.6(0.2)$ & $0.8(0.2)$ & $1.0(0.2)$ & $1.2(0.2)$ & $5.0(1.5)$ & $6.5(1.2)$ \\
\hline & Non-stream & $0.8(0.3)$ & $0.9(0.3)$ & $0.9(0.2)$ & $1.1(0.2)$ & - & - \\
\hline \multirow[t]{2}{*}{ Litter depth $(\mathrm{cm})$} & Stream & $2.0(0.5)$ & $2.2(0.7)$ & $3.5(0.3)$ & $2.5(0.4)$ & $51.7(3.8)^{\mathrm{a}, \mathrm{b}}$ & $60.7(7.1)^{\mathrm{a}, \mathrm{b}}$ \\
\hline & Non-stream & $4.4(1.6)$ & $3.0(1.2)$ & $6.1(1.7)$ & $4.9(1.9)$ & - & - \\
\hline
\end{tabular}

\footnotetext{
${ }^{a}$ Significantly greater than continuous results, $P<0.05$.

${ }^{\mathrm{b}}$ Significantly greater than MIRG results, $P<0.05$.

* MIRG: managed intensive rotational grazing.
}

\section{Discussion}

\subsection{Comparison of mammals between farm management styles}

Species richness, abundance and community composition were similar on MIRG and continuously grazed pastures. Therefore, there was no evidence that small mammals responded to the development of cover during "rest" periods on MIRG pastures. The cyclical growth pattern that characterizes these pastures is similar to that found on hayed fields. Results from a previous study on hayed fields (Sietman et al., 1994) suggest that habitats subjected to this type of disturbance do not support an extensive small mammal community, probably because hayed fields do not have the temporal habitat stability necessary to support an extensive small mammal community. Vegetation structure on both MIRG and continuously grazed pastures was also influenced by a variety of pasture management variables such as haying and the location and intensity of grazing. It may be that the confounding influence of these management variables overshadowed the effects of pasturing. The meadow vole was the most abundant species on both pasture types probably because this species is strongly associated with grassy, moist habitats typical of these areas (Jackson, 1961; Getz, 1970).

There were more animals, species and a different community of small mammals (including western harvest mice, Peromyscus spp., and short-tailed and masked shrews) on buffer sites compared to pasture sites. These results agree with Geier and Best (1980) who studied several habitat types (mostly forested) in agricultural Iowa and found the most diverse small mammal community in channelized, grassy habitats along streams which experienced only minimal disturbance from grazing, haying and herbicides. These results are probably because, in part, buffer sites combine small mammal communities using crop fields and buffer strips. Crop land in this region of North America is known to support small mammal 
communities dominated by Peromyscus spp. (Furrow, 1994; Marinelli and Neal, 1995). Alternatively, buffer strips provide extensive, undisturbed cover along stream areas which satisfy habitat requirements for a relatively large variety of small mammals found in southwestern Wisconsin such as meadow jumping mouse, meadow vole, short-tailed shrew and the masked shrew (Jackson, 1961). Buffer sites may also be more suitable for some species because buffer strips and crop fields each provide important resources in close proximity to one another (e.g. crop fields provide access to food and buffer strips provide nesting habitat and protection from predators). Some evidence for this was found as Peromyscus spp. and western harvest mice were captured in both buffer strips and crop fields and may have been using the different habitats in conjunction with each other.

Community structure in the buffer strips in our study were similar to those found in Nebraska prairies and roadside ditches, Iowa channelized riparian areas and Wisconsin prairies (Geier and Best, 1980; Kirsch, 1997; Anthony, 1999). However, the presence of prairie voles was a more important component of prairie and roadside ditch communities (Kirsch, 1997) than for the buffer sites or pastures in our study. This may reflect the relatively dry grasslands found in Nebraska roadside ditches that are presumably more conducive to prairie voles than more mesic Wisconsin riparian areas (Jones et al., 1983). Iowa channelized riparian communities were more heavily dominated by Peromyscus spp. (Geier and Best, 1980) than buffer strips in our study. In addition, meadow jumping mice contributed to small mammal communities on the buffer and pasture sites in our study but were not found in the Nebraska or Iowa channelized riparian areas (Geier and Best, 1980; Kirsch, 1997) and were rare in Wisconsin prairie (Anthony, 1999). This is not surprising considering that this species prefers wet grasslands typical of the riparian habitats in our study (Jackson, 1961). On pastures, thirteen-lined ground squirrels made a greater contribution in our study than to Wisconsin prairie communities (Anthony, 1999). This is also consistent with this species' habitat preference, in this case for short grass areas (Jackson, 1961). Land enrolled in the Conservation Reserve Program in Michigan that had been left fallow for greater than 2 years was found to be dominated by meadow voles and supported small mammal commu- nities similar in structure and composition to those found on pasture sites in our study (Furrow, 1994).

Numbers of small mammals captured on the pasture sites varied greatly between the 2 years of our study. When small mammals experience regionally high population densities, individuals of some species may be crowded out of preferred habitat into lower quality habitats (Getz, 1985). This "mass effect" (Shmida and Wilson, 1985) is enhanced in a heterogeneous landscape and suggests that species occurrence often depends on population dynamics associated with adjacent habitats. This phenomenon, then, may be responsible for the increase in small mammal richness and abundance on pastures from very low numbers in 1997 to much higher levels in 1998. Pastures in southwestern Wisconsin may function as secondary or "sink" habitat for small mammal species during high productivity years.

\subsection{Concentration of mammals near streams}

These results suggest that small mammal activity is concentrated near the stream, on the buffer sites and both pasture types. It is not surprising to observe this pattern on buffer sites based on previous studies that have found sparse small mammal communities associated with crop fields (Fleharty and Navo, 1983; Furrow, 1994; Marinelli and Neal, 1995) and relatively rich and abundant communities associated with ungrazed grassy areas (Geier and Best, 1980; Furrow, 1994; Hall and Willig, 1994; Kirsch, 1997; Anthony, 1999).

On pastures, however, the concentration of small mammals immediately adjacent to the stream appears to be related to characteristics other than vegetation structure. Meadow jumping mice were captured almost exclusively in stream areas on both pasture treatments. This result agrees with previous studies that suggest that meadow jumping mice are typically associated with grassy vegetation along streams (Whitaker, 1963) and tend to have movement patterns adjacent and parallel to waterways (Tester et al., 1993). Meadow voles, Peromyscus spp., and short-tailed shrews were also captured more frequently in stream areas. Flooding is common along streams in southwestern Wisconsin and these habitats are typically more mesic than non-stream areas increasing their suitability for meadow voles and short-tailed shrews. 
This makes sense for the meadow vole, a species that has been found to tolerate flooding and to prefer wet substrate (Lyon, 1958; Jackson, 1961; Murie, 1969; Getz, 1970). Short-tailed shrews are also believed to prefer moist habitats (Jackson, 1961). Peromyscus spp. are not known to prefer stream habitats over other areas although streams may have provided a natural "edge" effect, concentrating the activity of these species immediately adjacent to streams.

\subsection{Implications of stream-side farm practices for mammals}

This study does not suggest that a conversion from continuous grazing to MIRG practices will have a meaningful influence on small mammal communities by improving the quality of the pastures for small mammals. However, farm-wide implications of the conversion may benefit small mammals indirectly by causing a shift in the prevalence of pasture and crop field in the agricultural landscape. Conversion to MIRG practices involves a switch from a reliance on grain to grass production for feeding cattle. This often involves a conversion of farmland from cultivation of corn or soybean to pasture land (Jackson-Smith et al., 1996). MIRG pastures provide habitat suitable to more small mammal species than cultivated fields. As a result, the conversion from crop land to MIRG pasture will provide habitat for more small mammal species. Species like thirteen-lined ground squirrels, Peromyscus spp., meadow voles and meadow jumping mice are likely to benefit from this landscape trend. Even if riparian pastures represent demographic "sinks" for many of these species, their increased prevalence in the landscape may contribute to metapopulation size and stability (Howe and Davis, 1991).

This study suggests that legislation that will increase the prevalence of buffer strips in the landscape would provide habitat for a broad range of small mammals such as the meadow vole, short-tailed and masked shrews, meadow jumping mice, Peromyscus spp. and western harvest mice. The $7-15 \mathrm{~m}$ wide buffer strips in this study were sufficient to provide enough habitat to meet home range requirements for these species (Jackson, 1961). Furthermore, buffer strips appear to be used by species that use adjacent habitats, such as western harvest mouse and Peromyscus spp., perhaps acting as a refuge from predation pressure. Therefore, buffer strips may provide additional habitat for some species while improving the quality of adjacent habitats for others. Buffer strips in this study connected grassy habitats beyond the sampled area such as pastures, fields set aside from agricultural production and hayed fields. In the highly fragmented agricultural landscape, an increase in buffer strips along streams would increase connectivity within the landscape and may facilitate ecological exchange between otherwise isolated habitats (Noss, 1983; Gregory et al., 1991). This may be particularly important in the agricultural landscape, where species may rely on a complement of habitats to provide the range of resources required by that species.

\section{Conclusions}

Recently, conservationists have outlined the need for ecologists to describe systems in relation to land use practices and to work with economists, agronomists and policy developers with the goal of identifying possible scenarios that combine conservation and socio-economic goals (McCracken and Bignal, 1998). In the agricultural landscape this is a difficult challenge because the system has become fragmented, often leaving ecological components separated, each affected differently by different land use practices. For example, results from another component of this study that looked at grassland birds suggested that buffer sites were of little value for that group of species (Renfrew and Ribic, 2001). Further complicating the issue, as this study suggests, individuals of some species may have a home range that includes more than one habitat type. Nevertheless, land use in US agricultural areas changes quickly and it is important to understand the impacts that trends in land use may have for different components of the system and to encourage different management goals in different management units.

\section{Acknowledgements}

We thank the members of the Agroecosystems Research Group, University of Wisconsin, Madison, for all their help, particularly Laura Paine. We thank all 
the farmers who allowed us to work on their land as well as Dan Weiser, Jessica Czederpiltz, Jon Simonsen and Matt Lowann who participated in the field work. We thank Deb Ziebarth for administrative support. Mention of trade names does not imply endorsement for the use of any products. We thank two anonymous reviewers, Scott Craven, Richard Bautz, and Robert Seabloom for reviewing earlier drafts of this manuscript. Financial support for this project came from USFWS Partnerships for Wildlife, Wisconsin Department of Natural Resources, USDA Hatch Program, and the USGS BRD Wisconsin Cooperative Wildlife Research Unit.

\section{References}

Ad Hoc Committee on Acceptable Field Methods in Mammalogy, 1987. Acceptable field methods in mammalogy: preliminary guidelines approved by the American Society of Mammalogists. J. Mammal. 68, S1-18.

Anthony, N., 1999. The Wisconsin small mammal survey: a volunteer-based small mammal survey program for native grassland preserves in southern Wisconsin. Masters Thesis. University of Wisconsin-Madison, Madison, WI.

Barling, R.D., Moore, I.D., 1994. Role of buffer strips in management of waterway pollution: review. Environ. Manage. $18,543-548$.

Berger, W.H., Parker, F.L., 1970. Diversity of planktonic Foraminifera in deep sea sediments. Science 168, 1345-1347.

Castelle, A.J., Johnson, A.W., Conolly, C., 1994. Wetland and stream buffer size requirements - a review. J. Environ. Qual. 23, 878-882.

Curtis, J.T., 1959. The Vegetation of Wisconsin. University of Wisconsin Press, Madison, WI.

Fahrig, L., Merriam, G., 1985. Habitat patch connectivity and population survival. Ecology 66, 1762-1768.

Fleharty, E.D., Navo, K.W., 1983. Irrigated cornfields as habitat for small mammals in the sandsage prairie region of western Kansas. J. Mammal. 64, 367-379.

Furrow, L.T., 1994. Influence of field age on mammalian relative abundance, diversity, and distribution on C.P. lands in Michigan. Masters Thesis. Michigan State University, East Lansing.

Geier, A.R., Best, L.B., 1980. Habitat selection by small mammals of riparian communities: evaluating effects of habitat alterations. J. Wild. Manage. 44, 16-24.

Getz, L.L., 1970. Habitat of the meadow vole during a population low. Am. Midl. Nat. 83, 455-461.

Getz, L.L., 1985. Habitats. In: Tamarin, R.H. (Ed.), Biology of New World Microtus, No. 8. Special Pub. American Society of Mammalogists, Shippensburg, PA, pp. 286-305.

Gregory, S.V., Swanson, F.J., McKee, W.A., Cummins, K.W., 1991. An ecosystem perspective on riparian zones. BioScience 41, $540-551$.
Hall, D.L., Willig, M.R., 1994. Mammalian species composition, diversity and succession in Conservation Reserve Program grasslands. Southwest Nat. 39, 1-10.

Handley Jr., C.O., Kalko, E.K.V., 1993. A short history of pitfall trapping in America, with a review of methods currently used for small mammals. Virginia J. Sci. 44, 19-26.

Howe, R.W., Davis, G.J., 1991. The demographic significance of sink populations. Biol. Cons. 57, 239-255.

Jackson, H.H.T., 1961. The Mammals of Wisconsin. The Wisconsin University Press, Madison.

Jackson-Smith, D., Barham, B., Nevius, M., Klemme, R., 1996. Grazing in Dairyland, the Use and Performance of Management Intensive Rotational Grazing Among Wisconsin Dairy Farms. University of Wisconsin-Extension Technical Report 5, Madison.

Jones, J.K. Jr., Armstrong, D.M., Hoffman, R.S., Jones, C., 1983. Mammals of the Northern Great Plains. University of Nebraska Press, Lincoln.

Kauffman, J.B., Krueger, W.C., 1984. Livestock impacts on riparian ecosystems and streamside management implications: a review. J. Range. Manage. 34, 430-437.

Keppel, G., 1991. Design and Analysis, A Researcher's Handbook, 3rd Edition. Prentice Hall, Englewood Cliffs, NJ.

Kirsch, E., 1997. Small mammal community composition in cornfields, roadside ditches, and prairies in eastern Nebraska. Nat. Areas J. 17, 204-211.

Littell, R.C., Milliken, G.A., Stroup, W.W., Wolfinger, R.D., 1996. SAS System for Mixed Models. SAS Institute Inc., Cary, NC.

Lyon, J.N., 1958. Notes on mammals of southern Illinois. Am. Midl. Nat. 60, 219-254.

Magurran, A.E., 1988. Ecological Diversity and Its Measurement. Princeton University Press, Princeton.

Marinelli, L., Neal, D., 1995. The distribution of small mammals on cultivated fields and in rights-of-way. Can. Field Nat. 109, 403-407.

McCracken, D.I., Bignal, E.M., 1998. Applying the results of ecological studies to land-use policies and practices. J. Ecol. Appl. 35, 961-967.

Mosteller, F., Tukey, J.W., 1977. Data Analysis and Regression, A Second Course in Statistics. Addison-Wesley, Reading, MA.

Murie, J.O., 1969. An experimental study of substrate selection by two species of voles (Microtus). Am. Midl. Nat. 116, 106-123.

Nelson Jr., L., Clark, F.W., 1973. Correction for sprung traps in catch/effort calculations of trapping results. J. Mammal. 54, 295-298.

Noss, R.F., 1983. A regional approach to maintain diversity. BioScience 33, 700-706.

Pielou, E.C., 1969. An Introduction to Mathematical Ecology. Wiley, New York.

Platts, W.S., Wagstaff, F.J., 1984. Fencing to control livestock grazing on riparian habitats along streams: is it a viable alternative? N. A. J. Fish. Manage. 4, 266-272.

Rabeni, C.F., Smale, M.A., 1995. Effects of siltation on stream fishes and the potential mitigating role of the buffering riparian zone. Hydrobiologia 303, 211-219.

Renfrew, R.R., Ribic, C.A., 2001. Grassland birds associated with agricultural riparian practices in southwestern Wisconsin. J. Range. Manage. 54, 546-552. 
Robel, R.J., Briggs, J.N., Dayton, A.D., Hulbert, L.L., 1970. Relationships between visual obstruction measurements and weight of grassland vegetation. J. Range. Manage. 23, 295-298.

Shmida, A., Wilson, M.V., 1985. Biological determinants of species diversity. J. Biogeo. 12, 1-20.

Sietman, B.E., Fothergill, W.B., Finck, E.J., 1994. Effects of haying and old-field succession on small mammals in tallgrass prairie. Am. Midl. Nat. 131, 1-8.

Sokal, R.R., Rohlf, F.J., 1995. Biometry, 3rd Edition. Freeman, New York.

StatSoft, 1998. STATISTICA for Windows Volume I: General Conventions and Statistics I, 2nd Edition. StatSoft Inc., Tulsa, OK.

Tester, J.R., Malchow, S., Mclain, C., Lehrer, J.B., 1993. Movements and habitat use by meadow jumping mice in northwestern Minnesota. Prairie Nat. 25, 33-37.
Undersander, D.J., Albert, B., Porter, P., Crossley, A., 1992. Pastures for Profit: A Hands on Guide to Rotational Grazing. University of Wisconsin Extension Service No. A3529, Madison.

Weigel, B.M., Lyons, J., Paine, L.K., Dodson, S.I., Undersander, D.J., 2000. Using stream macroinvertebrates to compare riparian land use practices on cattle farms in southwestern Wisconsin. J. Freshwater Ecol. 15, 93-106.

Whitaker Jr., J.O., 1963. A study of the meadow jumping mouse, Zapus hudsonius, in central New York. Ecol. Monogr. 33, 215254.

Wisconsin Agricultural Statistics, 1996. Wisconsin Department of Agriculture, Madison.

Wohl, N.E., Carline, R.F., 1996. Relations among riparian grazing, sediment loads, macroinvertebrates, and fishes in three central Pennsylvania streams. Can. J. Fish. Aquatic Sci. 53, 260-266. 